\title{
SARS-CoV-2 SPIKE PROTEIN: an optimal immunological target for vaccines
}

\author{
Giovanni Salvatori ${ }^{1}$, Laura Luberto ${ }^{1}$, Mariano Maffei ${ }^{2}$, Luigi Aurisicchio ${ }^{1,2}$, Giuseppe Roscilli, ${ }^{1,2}$, Fabio Palombo ${ }^{1}$ \\ and Emanuele Marra ${ }^{1,2^{*}}$ (B)
}

\begin{abstract}
COVID-19 has rapidly spread all over the world, progressing into a pandemic. This situation has urgently impelled many companies and public research institutes to concentrate their efforts on research for effective therapeutics. Here, we outline the strategies and targets currently adopted in developing a vaccine against SARS-CoV-2. Based on previous evidence and experience with SARS and MERS, the primary focus has been the Spike protein, considered as the ideal target for COVID-19 immunotherapies.
\end{abstract}

Keywords: SARS-CoV-2, SPIKE protein, Vaccine

\section{Main text}

The outbreak of the novel coronavirus disease COVID19 , now officially designated as severe acute respiratory syndrome-related coronavirus SARS-CoV-2, has progressed rapidly into a pandemic. In just a few months, since December 2019, COVID-19 has spread worldwide with over 4.218.212 confirmed cases and more than 290.242 confirmed deaths as of May 14th, 2020 (WHO, Situation).

This dramatic situation calls for the rapid development of safe and effective prophylactics and therapeutics against infection of its causative agent. To date, no therapeutics or vaccines against any human-infecting coronaviruses have been approved.

Currently, ongoing strategies to trigger an effective immune response in humans against SARS-CoV-2 are taking advantage of previous experiences on other coronaviruses such as SARS-CoV and MERS-CoV. Since the SARS-CoV-2 virus shares striking structural similarity and sequence conservation with these two lethal coronaviruses, the immunization strategies exploited against

\footnotetext{
*Correspondence: marra@takisbiotech.it

${ }^{1}$ Takis s.r.l, Via di Castel Romano 100, 00128 Rome, Italy

Full list of author information is available at the end of the article
}

SARS and MERS viruses have been adopted in guiding the design of new SARS-CoV-2 vaccines.

Immunization with one or more SARS-CoV-2 subunit antigens, either administered as purified protein or expressed by viral, RNA or DNA vaccine vectors, is one approach to designing a vaccine.

Among the more likely targets for vaccination are the structural proteins that bedeck the surface of SARS$\mathrm{CoV}-2$. These include the envelope spike protein $\mathrm{S}$, the small envelope protein $E$, the matrix protein $M$ and the unexposed nucleocapsid protein $\mathrm{N}$.

An early study on recombinant vectors expressing the $\mathrm{S}$ protein of SARS-CoV found this protein to be highly immunogenic and protective against SARS-CoV challenge in hamster, while in contrast, the $\mathrm{N}, \mathrm{M}$, and $\mathrm{E}$ proteins did not significantly contribute to a neutralizing antibody response or protective immunity [1].

Evidence of the key role played by the $\mathrm{S}$ protein in counteracting coronavirus infection came from studies on human-neutralizing antibodies from rare memory B cells of individuals infected with SARS-CoV [2] or MERS-CoV [3]. In such studies, antibodies directed against the $\mathrm{S}$ protein of SARS-CoV were found effective in inhibiting virus entry into the host cells. More recently, it has been found that SARS-CoV S elicited polyclonal 
antibody responses, and vigorously neutralized SARSCoV-2 S-mediated entry into cells, thus further encouraging the use of this molecular target for vaccination and immunotherapies [4].

Structural studies of antibodies in complex with SARS$\mathrm{CoV} \mathrm{S}$ and MERS-CoV $\mathrm{S}$ have provided information about the mechanism of competitive inhibition to the host receptor. The receptor-binding domain (RBD) in SARS-CoV-2 $S$ protein was identified and found to bind strongly to ACE2 receptors [5]. SARS-CoV RBD-specific antibodies cross-react with SARS-CoV-2 RBD protein, and SARS-CoV RBD-induced antisera neutralized SARS$\mathrm{CoV}-2$, providing additional evidence that targeting this domain of the S protein of SARS-CoV-2 with a vaccine could be effective in preventive COVID-19 [5].

Given the above and that the coronavirus S glycoprotein is surface-exposed and mediates entry into host cells by interacting with angiotensin-converting enzyme 2 (ACE2), it rapidly became the main target of neutralizing antibodies and the focus of therapeutic and vaccine design.

Several companies and research institutes have started developing a vaccine that has the SARS-CoV-2 protein $\mathrm{S}$ as its target (see Table 1), although the various vaccination strategies show a differing ability to induce in the host both an antibody-mediated humoral response and a cell response mediated by $\mathrm{CD} 4$ or $\mathrm{CD} 8 \mathrm{~T}$ lymphocytes in preclinical models.

The evolving molecular heterogeneity of SARS-CoV has raised concerns about the breadth and efficacy of protection provided by specific vaccine strains and the possible development of immune escape. However, it has been observed that a heterotypical response blocking SARS-CoV-2 S-mediated entry into host cells is elicited, coinciding with the sequence and structural conservation of SARS-CoV-2 and SARS-CoV S protein, suggesting that immunity against one virus can potentially provide protection against related viruses.

One of the most perplexing questions regarding the current COVID-19 coronavirus epidemic is the possible worsening of the disease by immunotherapies, as the consequence of an antibody dependent enhancement (ADE) of infection with SARS-CoV-2. ADE of viral entry has been a major concern for epidemiology, vaccine development, and antibody-based drug therapy. ADE viral entry into the target cell of SARS-CoV-2 is mediated by the Fc receptor II and not by its canonical receptor. It has been suggested that ADE may explain geographical differences in the severity of COVID-19 due to prior exposure to similar antigenic epitopes [6].

One study showed that the antibody against SARS$\mathrm{CoV}$ spike protein potentiated infection of monocytes.

Table 1 Developmental vaccines targeting SARS-CoV-2 protein S (Adapted from BioWorld, company sites, Thomsen Cortellis, PubMed)

\begin{tabular}{|c|c|c|}
\hline Companies & Vaccination typology & Current development stage \\
\hline Altimmune & $\begin{array}{l}\text { A replication-defective adenovirus vector } \\
\text { incorporating the SARS-CoV-2 S protein } \\
\text { administered by an intranasal single-dose }\end{array}$ & $\begin{array}{l}\text { The vaccine design and synthesis steps are completed. } \\
\text { Moving toward preclinical tests and manufacture, } \\
\text { hoping to start phase } 1 \text { trial at mid-August }\end{array}$ \\
\hline CanSino biologicals & Adenovirus type 5 vector that expresses $\mathrm{S}$ protein & $\begin{array}{l}\text { Phase I (NCT04313127) completed Phase II started: It is } \\
\text { China's first recombinant vaccine candidate for novel } \\
\text { coronavirus entering Phase II of a human clinical trial, } \\
\text { with } 500 \text { volunteer participants }\end{array}$ \\
\hline $\begin{array}{l}\text { (Sichuan) Clover Biopharmaceuticals } \\
\text { (Chengdu, China) Partnered with } \\
\text { GlaxoSmithKline }\end{array}$ & $\begin{array}{l}\text { Recombinant SARS-CoV-2 S-protein trimer subunit } \\
\text { produced by its patented Trimer-Tag® technology }\end{array}$ & $\begin{array}{l}\text { Carrying out preclinical tests with GlaxoSmithKline's } \\
\text { pandemic vaccine adjuvant technology and in } \\
\text { collaboration with Dynavax, proprietary holder of toll- } \\
\text { like receptor } 9 \text { agonist adjuvant, CpG } 1018\end{array}$ \\
\hline Inovio Pharmaceuticals & $\begin{array}{l}\text { Electroporation of DNA INO-4800 encoding SARS- } \\
\text { CoV-2 S protein }\end{array}$ & $\begin{array}{l}\text { Started trial in United States (Phase } 1 \text { NCT04336410). } \\
\text { There are already } 3000 \text { doses available }\end{array}$ \\
\hline $\begin{array}{l}\text { LineaRx Takis Biotech (Rome) to } \\
\text { clinical test candidates in Italy }\end{array}$ & $\begin{array}{l}\text { Electroporation of linear DNA encoding S protein or } \\
\text { its specific portions }\end{array}$ & $\begin{array}{l}\text { Five candidates have been designed of linear DNA } \\
\text { vaccine based on S protein and selected epitopes, ready } \\
\text { for testing by the beginning of May or June }\end{array}$ \\
\hline Moderna & $\begin{array}{l}\text { The mRNA encoding SARS-CoV-2 S protein is } \\
\text { encapsulated in ionizable lipid, distearoyl } \\
\text { phosphatidylcholine, cholesterol and polyethylene } \\
\text { glycol lipid }\end{array}$ & Phase 1 (NCT04283461) testing is underway \\
\hline Novavax & $\begin{array}{l}\text { Nanoparticle displaying SARS-CoV } 2 \text { S protein with } \\
\text { saponin-based (Matrix-M) adjuvant }\end{array}$ & $\begin{array}{l}\text { Currently assessing the candidates in animal models, } \\
\text { expecting to start Phase } 1 \text { trial in June } 2020\end{array}$ \\
\hline $\begin{array}{l}\text { University of Queensland (Brisbane, } \\
\text { Australia) }\end{array}$ & $\begin{array}{l}\text { Recombinant subunit of SARS-CoV- } 2 \text { S protein } \\
\text { locked in prefusion conformation by polypeptide } \\
\text { moiety (molecular clamp) }\end{array}$ & $\begin{array}{l}\text { In preclinical testing, partnering with Dynavax } \\
\text { Technologies Corp. in collaboration with } \\
\text { GlaxoSmithKline plc and Seqirus GmbH }\end{array}$ \\
\hline
\end{tabular}


However, ADE-infected macrophage did not support the productive replication of SARS-CoV, and no detectable release of progeny virus was observed [7]. In a mouse model of vaccination for SARS-CoV with different approaches including inactivated virus, DNA or recombinant spike (S) protein, vaccines lead to pulmonary immunopathology. However, despite deterioration in the pulmonary histopathology profile of the vaccinated mice, all the SARS-CoV vaccines induced antibody and protection against infection with SARS-CoV [8].

It has been found that higher concentrations of antisera against SARS-CoV neutralized infection, while highly diluted anti-sera significantly increased SARS$\mathrm{CoV}$ infection. Results from infectivity assays indicate that SARS-CoV ADE is primarily mediated by diluted antibodies against envelope spike protein [9]. However, the relevance of $\mathrm{ADE}$ in coronavirus infections remains elusive, as no direct evidence of it has been found in various vaccination models [5]. Accordingly, it has been shown that vaccination of the Rhesus Macaque monkey with an attenuated SARS-CoV revealed no exacerbation of infection even several weeks after vaccination, when the antibody titer was reduced [10].

It is of relevance that several companies are involved in the development of a vaccine against the spike protein of SARS-CoV-2, exploiting different strategies such as purified protein or expressed by viral, RNA or DNA vaccine vectors. This target has been guided by previous preclinical history of the proven efficacy of immunotherapies against the homologous protein of SARS-CoV. Although the ADE effect of non-neutralizing antibodies directed against the SARS-CoV-2 S protein remains controversial, safety testing of COVID-19 S protein-based B cell vaccines in animal models is strongly encouraging prior to clinical trials. Given the urgency of an effective vaccination to prevent the spread of SARS-CoV-2, this plurality of approaches in vaccine generation with complementary strategies, paves the way to a wider immunotherapeutic spectrum, thus increasing the chances of success in such a short time frame.

\section{Abbreviations}

ACE2: Angiotensin-converting enzyme 2; RBD: Receptor-binding domain; ADE: Antibody dependent enhancement.

\section{Acknowledgements}

Not applicable.

\section{Authors' contributions}

EM and GS wrote the manuscript with contributions from all the authors. All authors read and approved the final manuscript.

Funding

Not applicable.
Availability of data and materials

Not applicable.

Ethics approval and consent to participate

Not applicable.

Consent for publication

Not applicable.

\section{Competing interests}

Laura Luberto, Mariano Maffei, Luigi Aurisicchio, Giuseppe Roscilli, Fabio Palombo and Emanuele Marra are employees at Takis Biotech and Evvivax, which are developing a vaccine against COVID-19.

\section{Author details \\ ${ }^{1}$ Takis s.r.l, Via di Castel Romano 100, 00128 Rome, Italy. ${ }^{2}$ Evvivax s.r.l, Via di Castel Romano, 100, 00128 Rome, Italy.}

Received: 22 April 2020 Accepted: 28 May 2020

Published online: 03 June 2020

\section{References}

1. Buchholz UJ, Bukreyev A, Yang L, Lamirande EW, Murphy BR, Subbarao $\mathrm{K}$, et al. Contributions of the structural proteins of severe respiratory syndrome coronavirus to protective immunity. Proc Natl Acad Sci USA. 2004;26:9804-9.

2. Traggiai E, Becker S, Subbarao K, Kolesnikova L, Uematsu Y, Gismondo MR, et al. An efficient method to make human monoclonal antibodies from memory B cells: potent neutralization of SARS coronavirus. Nat Med. 2004;10:871-5.

3. Corti D, Zhao J, Pedotti M, Simonelli L, Agnihothram S, Fett C, et al. Prophylactic and postexposure efficacy of a potent human monoclonal antibody against MERS coronavirus. Proc Natl Acad Sci USA. 2015;112:10473-8.

4. Walls AC, Park YJ, Tortorici MA, Wall A, McGuire AT, Veesler D. Structure, function, and antigenicity of the SARS-CoV-2 spike glycoprotein. Cell. 2020;180:1-12.

5. Tai W, He L, Zhang X, Pu J, Voronin D, Jiang S, et al. Characterization of the receptor-binding domain (RBD) of 2019 novel coronavirus: implication for development of RBD protein as a viral attachment inhibitor and vaccine. Cell Mol Immunol. 2020. https://doi.org/10.1038/s41423-020-0400-4.

6. Tetro JA. Is COVID-19 receiving ADE from other coronaviruses? Microbes Infect. 2020;22:72-3.

7. Yip MS, Leung NHL, Cheung CY, Li PH, Lee HHY, Daëron M, et al. Antibody-dependent infection of human macrophages by severe acute respiratory syndrome coronavirus. Virol J. 2014;11:82.

8. Te Tseng C, Sbrana E, Iwata-Yoshikawa N, Newman PC, Garron T, Atmar RL, et al. Immunization with SARS coronavirus vaccines leads to pulmonary immunopathology on challenge with the SARS virus. PLOS ONE. 2012;7:4.

9. Wang SF, Tseng SP, Yen CH, Yang JY, Tsao CH, Shen CW, et al. Antibodydependent SARS coronavirus infection is mediated by antibodies against spike proteins. Biochem Biophys Res Commun. 2014;451:208-14.

10. Luo F, Liao FL, Wang H, Tang HB, Yang ZQ, Hou W. Evaluation of Antibody-Dependent Enhancement of SARS-CoV Infection in Rhesus Macaques Immunized with an Inactivated SARS-CoV Vaccine. Virol Sin. 2018;33:201-4.

\section{Publisher's Note}

Springer Nature remains neutral with regard to jurisdictional claims in published maps and institutional affiliations. 